\title{
BENOA BAY RECLAMATION: THE IMPACT OF POLICY-MAKING FOR SOCIAL AND ENVIRONMENT
}

Yulinda Adharani ${ }^{1 *}$, Nadia Astriani ${ }^{2}$, Siti Sarah Afifah $^{3}$

${ }^{1 * 2,3}$ Faculty of Law, Universitas Padjadjaran, Bandung, Indonesia.

Email: ${ }^{*}$ yulinda.adharani@unpad.ac.id, ${ }^{2}$ nadia.astriani@unpad.ac.id, ${ }^{3}$ sitisarahafifah@gmail.com

Article History: Received on $15^{\text {th }}$ May 2020, Revised on $10^{\text {th }}$ August 2020, Published on $17^{\text {th }}$ September 2020

\begin{abstract}
Purpose: The purpose of this article to discover how policy-making that made by the Indonesia government related to the development of Bali Benoa Bay reclamation so that the environment around Benoa Bay stays sustain and the local community does not feel threatened by the development of Benoa Bay Reclamation, especially the Adat community.
\end{abstract}

Methodology: This article is a result of legal studies using the normative juridical method. First, a complete, thorough, and comprehensive approach becomes the base in identifying the subject matter of the problem. Second, it is made to know and understand the policy in settling the problems in spatial planning from the legal aspect of (Seokanto \& Mamudji, 1994).

Main Findings: Policy change on Benoa Bay status affected social and environmental aspects. The policy that the Indonesia government made was led to a huge environmental impact on Benoa Bay. The status changed of Benoa Bay from a conservation area to an exploitation area can be a threat to the marine ecosystem and the migratory species, because in Presidential Regulation Number 54 the Year 2014 stated that it can develop reclamation in Benoa Bay.

Implications/Applications: This study discusses theories about environmental law, and analyzes them against cases so that sustainable development can be achieved. Policy or decision making must base on the use of the best information and the best science available, and in some situations, it is appropriate regarding environmental, social, and cultural factors.

Novelty/Originality of this study: As far as we are concerned, an environmental problem in Bali not particularly noticed in the development plan of the reclamation of Benoa Bay that caused by policy-making and the effect to the society and environment, this article is an attempt to viewed from a different side in addition to tourism in Bali.

Keywords: Reclamation, Benoa Bay Bali, Environmental Law, Traditional Society, Sustainable Development.

\section{INTRODUCTION}

Indonesia is known as a maritime country, because it has territory the waters are quite extensive, with the most islands in the world, around 17,502 islands. Country Indonesia is known as the fourth largest population in the world after China, India, and America. Indonesia's population in 2017 is estimated to reach almost 262 million inhabitants (Rahmah, 2019). Bali is an Island of the most popular tourism in Indonesia, in April 2016 Bali government tourism office released the statistical data that shows the number of foreign arrivals to Bali reached 1.4 million people. Bali is about their culture, indigenous people and knowledge, and the beautiful beach. But nowadays, the traffic jam and the plastic waste at the beach because of the uncontrollable tourist are dominating in Bali. Because of that, the Indonesia government has planned to build an artificial island/reclamation at Benoa Bay.

Benoa Bay is a tidally influenced shallow lagoon $\left(25-30 \mathrm{~km}^{2}\right)$ covered by mangroves in the innermost parts and with some patchy distributed submerged rooted vegetation in the gullies. The tidal flats dry out at low water. Channels that never dry traverse the bay. On tidal flats, randomly distributed spots of macroalgae occur. The water in the bay is slightly turbid and under-saturated concerning oxygen (Bach et al., 1998).

The plan prompted criticism from environmental activists and local communities, who say the Benoa Bay reclamation project, valued at 30 trillion rupiahs ( $\$ 2$ billion), would clear much of the bay's rich mangrove ecosystem that feeds the local fishing community (Gokkon, 2019).

Based on Presidential Regulation Number 45 the Year 2011 on Urban Regional Spatial Plan For Denpasar, Badung, Gianyar, and Tabanan, Benoa Bay is categorized as a conservation area. But the policy was revised to Presidential Regulation Number 51 the Year 2014, which turned the status of Benoa Bay from a conservation area into a commercial area. The basic ground of this change was also supported by the belief that because of the rapid development of the hotel, commercial areas, and tourism on Bali island will provide more income to the government especially the local government and society, which is still polemic.

The issuance of Presidential Decree No. 51 of 2014 abolished articles stating that Benoa Bay is a conservation area as mentioned in Article 55 paragraph 5 of Presidential Decree No. 45 of 2011 as well as reducing the extent of water conservation areas by adding the phrase "partial" to the conservation area of Serangan Island and Pulau Pudding This causes the conservation area in the SARBAGITA area to decrease in size. Presidential Decree No. 51 of 2014 was born only to accommodate the 700 ha Benoa Bay reclamation plan. This is considered detrimental to the people of Bali and does not provide justice to them (Triana, 2019). 
In other words, the Government of Indonesia has allowed building an artificial island/reclamation in Benoa Bay. The 700 hectares of a mangrove conservation area, perfect marine ecosystems, and oceanfront will be converted into a tourist haven of hotels, golf courses, luxury shopping and include a theme park and race track. This can happen because the Ministry of Maritime Affairs and Fisheries has issued a location permit in that area. The movement, protests, and demonstrations have sparked by local citizens and environmental communities, they are concerned that the reclamation will kill livelihoods and even damaging the marine ecosystem. The coral reefs in Tanjung Benoa, which a part of whole marine ecosystems in Benoa, are very vulnerable to mild particles of sediment. The development of reclamation will bring small sediment particles and cause the coral to die because the underwater area was covered by it.

The articles which stated Benoa Bay is a conservation area was removed from the revision of Presidential Regulation Number 45 the Year 2011 on Urban Regional Spatial Plan For Denpasar, Badung, Gianyar, And Tabanan, for the change on Article 101A stated that revitalization activities including the reclamation development of the most extensive 700 hectares can be carried out on Benoa Bay. Because of that revision, the protected status of 1,375 hectare Taman Hutan Raya Ngurah Rai mangrove forest was stripped, and they downgraded into a buffer zone that allowing the activities to develop the area. In 2014, the Indonesian Ministry of Maritime and Fisheries issued a location permit, issuance of location permit is the basis for investors to obtain an environmental permit.

If the reclamation has been built at the Benoa Bay, it would be affected the seawater of Benoa Bay, so that it also affected the coastal ecosystem sustainability. In recent years, the degradation of environmental quality has become a serious issue and one of them is caused by the increased development activities exploiting the coastal areas (Hendrawan

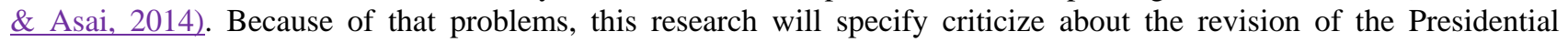
Regulationrevisions that led to reclamation development and the impact on the social and environment.

\section{Coastal Regulation and Policy}

Science and policy-making are different from one another but complementary. The conduct of each requires different sets of expertise. The scientists must know theory, methodology, and techniques. The policy-maker must know constituencies, governance processes, and value orientations expressed as legal mandates. In the case of coastal environmental mitigation strategies, a scientist may tell us what mitigation techniques will lead to a certain outcome, but not whether or how much of that mitigation or particular outcome is appropriate. A scientist may identify an effective, cost-efficient indicator of a certain condition in the environment, but not whether or not the condition so identified is acceptable (Rizal, 2018).

Mostly, the coastal terrain is dominated by scientific and technological disciplines. The importance of biology, scientific gauges, measurements, and the like in the coastal zone and their contribution (Foxwell-Norton, 2017). The social and biophysical sciences are an important information source but are often neglected in policy and practice. The literature has identified the science, policy practice gaps as significant barriers to the sustainable management of coastal resources (Dale et al., 2019).

Reclamation definition according to several reference sources is as follows: Reclamation can be generally understood as the process of restoring a beach from erosion. Sand is added to the areas of the beach that have experienced severe erosion to "reclaim" the shoreline of the beach (Strzałkowski, 2019). According to the Law of the Republic of Indonesia No. 27 of 2007 on the Management of Coastal Areas and Small Islands, reclamation is activities carried out by people to increase the benefits of land resources viewed from the environmental and socio-economic by landfilling, land drying, or drainage.

Presidential Regulation of the Republic of Indonesia Number 122 of 2012 Concerning Reclamation in Coastal Areas and Small Islands Article 26, explains the implementation of reclamation must maintain and pay attention to a. sustainability of people's lives and livelihoods; b. a balance between the interests of the utilization and importance of the preservation of the functions of the coastal environment and small islands; and c. technical requirements for material collection, dredging, and storage (Article 26 Presidential Regulation of The Republic of Indonesia Number 122 concerning Reclamation in Coastal Areas and Small Islands, 2012).

The construction of coastal areas has caused significant environmental impact demonstrating a need for proper management and planning informed by science (Stocker, 2015). Science is used to inform work on relevant disciplines from the natural, physical, and social sciences (Holmes, 2008). Scientists should recognize where scientific knowledge may actually enable or inform a decision and target their research explicitly. Scientists might best acquire acumen of the constantly evolving policy space through developing relationships with policymakers, attending policy events, and keeping abreast of policy processes and outputs (Marshall, 2017).

Based on research by Shanghai Ocean University, marine environment policies show a remarkable positive space autocorrelation in the coastal areas generally, with remarkable clustering phenomena locally. The study also shows that the traditional regression method isn't suitable for quantitative analysis of marine environmental policy, but Spatial Model is the best choice (Jiping, 2016).

Spatial and conservation planning of the urban development in marine environments is therefore as important as in terrestrial and urban habitats and should be used to prevent or mitigate the impacts of artificial structures (Dafforn, 
2015). Considering the potential damage that artificial structures can cause in the marine environment, where and when such structures are constructed should be regulated, taking into consideration essential ecosystem services provided by marine systems (Böhnke-Henrichs, 2013).

\section{Environment Regulation and Policy}

Munadjat Danusaputro said that the environmental problem in Indonesia has 4 factors: Population, Poverty, Pollution, and Policy. These environmental problems must be tackled as a whole together because they are closely related and influence each other. Therefore, the movement to overcome and overcome environmental problems is interpreted: "a new liberation movement to free men from the threat of their thraldom to environment perils of their own making" (Priyanta, 2015). Policy as one of the environmental problems. Because nowadays as we know, if the policymakers are not considering the environment so the policy will harm the environment (Black, 2016). Environmental policy is an important tool in local government regulation. Ma et al. (2020) believe that local government competition makes environmental pollution worse (Ma, et al., 2020).

Environmental issues are fertile ground for the study of learning because they are characterized by high levels of uncertainty associated with cross-scale feedbacks, unclear problem definition and resolution, and diverse policy interests. The learning function is the basis of policy-oriented learning or alterations in thought or intentions, and one path for belief and policy change in the ACF (Dale et al., 2019).

The law will be an essential vehicle for implementing policy, as "law provides the basis for policies aimed at changing behavior to promote or inhibit adaptation actions before damage is suffered and a framework for responding to losses after the event" (Shakeela, 2015). The domain of environmental law and policy extends to any place where the earth is modified by human activities or actions (Percival et al., 2017). John Holdren and Paul Ehrlich are suggesting that the impact that human behavior has on the environment results from the combined effect population size, the level of affluence, and the type of technologies that enhance our abilities to consume resources (Ehrlich \& Holdren, 1971).

Environmental policy depends for its success on public participation. However, the scientific construction of environmental issues often means that such participation in policy-making is difficult when the public is not considered scientifically 'expert' (Eden, 2016). During past decades, environmental policy has merged as major issues. As a consequence of countless environmental threats, the environment has captured the public mind.

\section{RESEARCH MATERIALS AND METHODS}

This article is a result of legal studies using the doctrinal method. First, A complete, thorough, and comprehensive approach becomes the base in identifying the subject matter of the problem. Second, it is made to know and understand the policy in settling the problems in social and environmental from the legal aspect (Soekanto \& Mamudji, 1994). Data are collected through studies using books, articles, research results, laws, and regulations (Tarigan, 2020). A literature review was conducted at the start to help identify pertinent issues and shape the research. The researcher took written notes of the interviews and produced a synthesis of the key issues raised by the interviewees. To enable the more detailed analysis required, digital recordings were made of the interviews and converted into written transcripts by transcribers. Data collection and analysis for both phases were shaped by the researchers' understandings of the impact of policy-making for social and environment, especially on the Benoa Bay reclamation plan. This understanding was informed by the literature, discussions with representatives from NGOs, the staff of Ministries, and the researchers' previous experience.

\section{RESULT AND DISCUSSION}

\section{The Impact of Policy For Sustainable Environment at Benoa Bay}

\section{Environmental Development Concept}

Inside the coastal zones in Indonesia, there are includes a diversity of ecology, biology, economics, political issues, cultural and moral positions. Emphasized by a diversity of theoretical, religious, philosophical, and moral doctrines that are more just and more resilient than those based on a single paradigm, sought now for consensus on the types of social and economic that can be used are sustainable coastal resources and investment. However, it must be discussed, it is not the only source of criteria that is approved for sustainable development. Since a long time ago until now, the coastal zone is an important part of people in Indonesia for political and economic reasons. They provide the closest natural habitat for the closest inhabitants of cities and towns. Coastal resources in Indonesia are always used by local people to get food, animal feed, firewood, shelter, and various other services. With high biodiversity and endemism, these coastal resources are in great demand for national economic development (Sukardjo, 2002).

Development in the broadest sense is an effort to change the condition of a nation for the better. Development is associated with state goals generally carried out to realize a just and prosperous society. Resources become one of the important development of capital. Human resources and natural resources are basic needs for developing countries. The use of natural resources as development capital, since the industrial revolution and the implementation of world development programs in the 1960s have had an impact on the environment. Rachel Carson published a paper entitled 
The Silent Spring which inspired American society that the development carried out in realizing the welfare of the community had an impact on the decline of environmental functions in supporting human life.

The phenomenon of environmental impact shows the world community that development contains a dual aspect, as well as the terms of change included in it, where change is a term that can mean progress can also mean regress. Development in a positive connotation is progress, but on the other hand, it can potentially be a setback, where the negative impacts of development begin due to the energy crisis and global environmental damage, human moral decline, shifting human values from human values to material values. Environmental Impact Assessment (EIA) is guidance for decision-making. Arrangement of EIA purposes is to integrating environmental deliberations for decision-making, preventing or minimalizing adverse impacts, protecting the environment, and their ecological processes to achieve sustainable developments (Noble, 2012).

Human interference such as coastal reclamation caused to determine changes of the natural shoreline. The natural coastline occurs at the crossing of water and land surfaces and is detected by digitization techniques (Boak \& Turner, 2005). The term reclamation is a derivative of the English term reclamation derived from the verb reclaim which means to take back, with emphasis on the word "return". In the construction technique, the term reclaim is also used in the example of reclaiming materials from former buildings or from debris, such as rocks and gravel from former road construction, or gravel from concrete debris to be used again (Soehoed, 2004).

This century is marked by the rapid emergence and intensification of human uses of the oceans that present immense economic opportunity, but if not managed properly, could lead to an over-crowded and dysfunctional seascape with serious environmental impacts and costly socioeconomic conflicts (Lester, 2018).

Coastal zone is one of the important areas for biodiversity, and they are one of the main ecosystems of the Indonesia biosphere. In determining system responses to environmental change, biodiversity plays an important role both at the functional (species groups) and structural (community) levels (Cearreta et al., 2002).

Now, either as disposals area for the industrial and domestic waste or as main places for developing an artificial island/reclamation for industry or agriculture or settlement, the coastal resources are under pressure. Furthermore, during the last decade, especially in Java, large cities have continued very rapidly; and the coastal zone disturbed enough because of this growth. Besides, Indonesia's population is rapidly increasing, approaching 215 million by the year 2000. Also, about $60 \%$ of the Indonesian people live in and around coastal areas, making managing the coastal zone in Indonesia even more complicated (Sukardjo, 2002).

\section{Case of Benoa Bay Reclamation}

Several projects in Bali have been in the public spotlight to date, starting from the plan of PT TWBI, the construction of a resort on Menjangan Island which is included in the West Bali National Park area, development of ecotourism and luxury villas in the Nature Tourism Park (TWA), Hutan Dasong Buyan-Tamblingan. These tourism investment projects cannot be viewed in isolation. They show a consistent character in the contemporary Balinese development model (Wardana, 2017).

Benoa Bay (situated between latitude 8o43'30" to 8o43'47" and longitude 115o10'30" to 115o13'30") is a small tidal semi-enclosed bay with the inner bay size of $10 \mathrm{~km}$ x $15 \mathrm{~km}$ with a narrow gap formed by Serangan Island and Tanjung Benoa. Benoa Bay is in the southern part of Bali Island is a strategic area that is connected to the Indian Ocean through a narrow entrance. Therefore, this area is located in the alley of city development, tourism zone, and centers of national and international transportation (airport and port). Benoa port, recognized as an international port and is located inside the bay. Benoa Bay is geographically bordered by cape (Tanjung) to the south, Ngurah Rai International airport to the west, and Serangan Island to the east. The Benoa Bay is surrounded by mangrove forests in shallow water varying in depths from $2 \mathrm{~m}$ to $15 \mathrm{~m}$ and oral covers the seafloor of the bay (Dharma \& Candrayana, 2017).

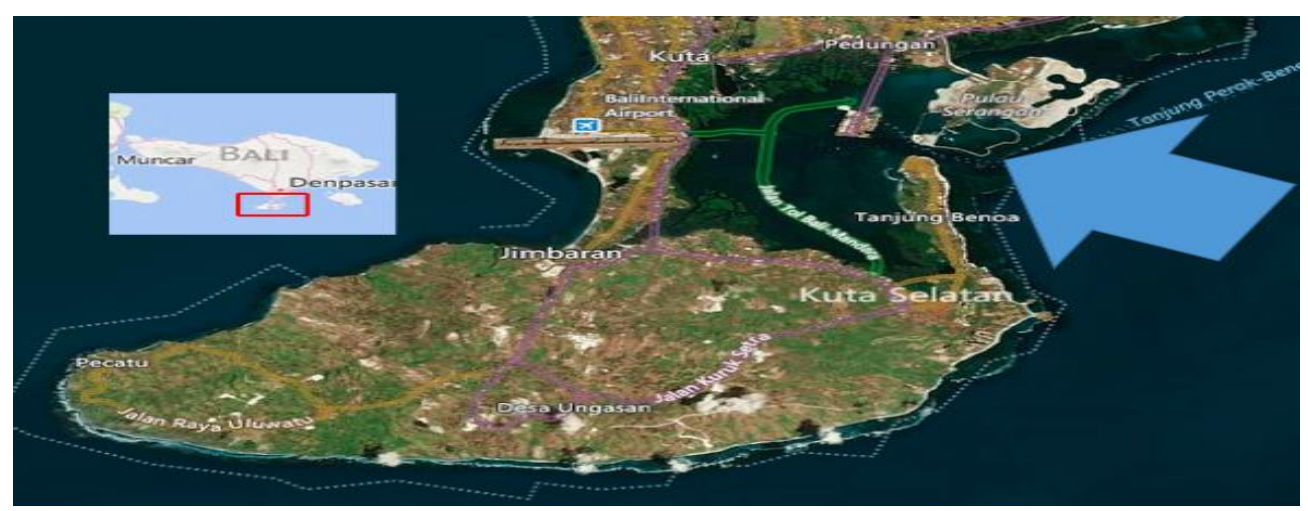

Figure 1: Map of Benoa Bay Bali

Source: Google Earth, 2018 
Munadjat Danusaputro said that the environmental problem in Indonesia has 4 factors: Population, Poverty, Pollution, and Policy. Policy as one of the environmental problems. Because nowadays as we know, if the policymaking is not considering the environment so the policy will harm the environment. Concerning the factor of environmental problem in Indonesia, in this case of Benoa Bay status changed from conservation area to cultivation area is the part of the policy factor that caused the problem to the environment. According to Presidential Regulation Number 45, the Year 2011, Benoa Bay is categorized as a conservation area. But in 2014, the policy was revised to Presidential Regulation Number 51 the Year 2014, which turned the status of Benoa Bay from a conservation area into a commercial area. In other words, the Government of Indonesia has given the opportunity to build an artificial island/reclamation in Benoa Bay.

Before issuing Presidential Regulation Number 51 In 2014, the Governor of Bali, Made Mangku Pastika has issued Decree Number 2138/02-C/HK/2012 regarding the management Benoa Bay territorial waters covering an area of 838 $\mathrm{Ha}$, with a plan of $438 \mathrm{Ha}$ to be built mangrove forest, about $300 \mathrm{Ha}$ built public facilities such as art centers, buildings craft fairs, sports arenas, places of worship, schools, etc., and only a small part or about 100 ha was built tourism accommodation. Based on the Decree of the Governor of Bali regarding the policies of the Bali Provincial Government, utilization permit recommendations are issued. The recommendation should still need some supporting studies, synchronization, and harmonization with laws and regulations, as well as several mandatory licensing stages owned by investors, where these permits are under the authority of the Government Regency/City (Dewi, 2019).

As we can see in figure 2 the decrease of the conservation area at Benoa Bay (marked in purple color), at the right figure is Presidential Regulation No. 45 of 2011 and at the left figure is based on Presidential Regulation No. 51 of 2014 . based on the Minister of Public Works Regulation No. 40/PRT/M/2007 on Spatial Planning Guidelines for Coastal Reclamation Region stated that reclamation NOT RECOMMENDED but can be done concerning some provisions beyond the mangrove forest which part of the protected areas or national parks, nature reserves, and wildlife reserves. (Ministry of Public Works Indonesia) Benoa Bay is an area with mangrove forests where reclamation is carried out in the mangrove forest area, and this will damage the ecosystem around mangrove.

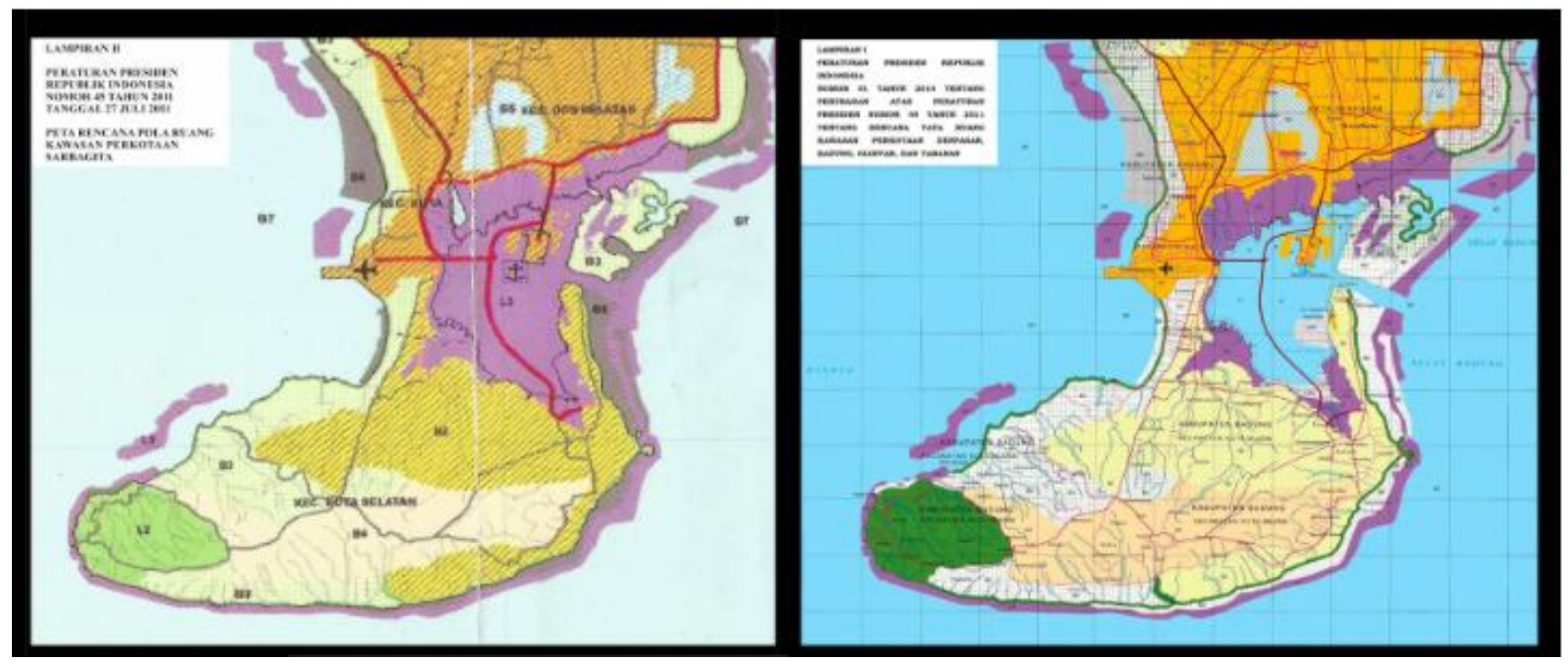

Figure 2: Comparison Map Between the Two Presidential Regulation Impact to Conservation Area at Benoa Bay.

Source: For Bali, 2018

Benoa Bay is the main object for most of the tourism, recreational, and economic developments. If the reclamation has been built at the Benoa Bay, it would affect the seawater of Benoa Bay. On the coastal ecosystem sustainability, seawater in the coastal area has a significant role. Nowadays, because of development activities increasing and interfering the coastal areas, environmental degradation has become a serious issue. Seawater salt various contaminants either straight away from pollutant origins or implicitly from the river downstream (Hendrawan \& Asai, 2014). The main flow of seawater in the coastal region is sturdily influenced by the tidal system, furthermore to that induced by the river stream. Hence, appropriate research of the tidal flow in coastal waters becomes one of the most important environmental sciences (Imasato et al., 1980).

So it can be said that Presidential Regulation Number 45, the Year 2011 No 51 of 2014 as a form of symbolic violence committed by the Government as the dominant group to the marginalized groups which led to the conflict with the society.

\section{Biodiversity at Benoa Bay}

In the Convention on Biological Diversity, biodiversity is defined as the variability among all organisms. Not only arise from various species of fauna and flora but a variety of species also arise from a variety of genetics which are variations in one species, one of which is related to the location, as well as a variety of ecosystems related to various ecosystems such as forests, rivers, tides and coral reefs, which are composed of the interrelation between various fauna and flora. 
The ecosystem can give blessings to people where various organisms interact, its called ecosystem services, ecosystem services including (Field et al., 1998):

1. "Provisioning services" of resources such as genetic resources for medicine and seafood,

2. "Regulating services" for clean water and stable climate,

3. "Cultural services" to provide recreational benefits such as sea bathing, and

4. "Supporting services" such as photosynthesis and nutrient circulation.

In the coastal area, the development project usually creates physical transformations of the coastline that lead to losses of seaweed beds, tidal flats, and coral reefs. If this transformation occurs, it is likely also have an impact on the location of migratory birds if the birds pass through the area, then this should be a concern to the government.

Reclamation activities in waters have a high potential to cause sedimentation. This is similar to the results of a study by Wisha et al. (2018) which predicts hydrodynamic balance will decrease which results in increased sedimentation rate if a reclamation is carried out in Benoa Bay. Sedimentation that increases directly will also affect the condition of aquatic ecosystems in Benoa Bay. Coral ecosystems are very sensitive to turbidity, one of which is caused by sedimentation in water (Fabricius, 2011). Environmental activists say that the coral reefs and beaches in Benoa Bay must be protected, especially since this area is part of a nature reserve (DW, 2016).

Reclamation has the potential to increase the level of turbidity of the waters which will spread beyond the Bay. This has the potential to damage the ecosystem outside Benoa Bay which is considered to be able to recover after the previous activities, so that development must be carried out sustainably and ecosystem-based (Asri et al., 2018).

The waters of Benoa Bay have indeed been damaged and polluted since the reclamation of Serangan Island on 19951996, the construction of the Mandara toll road on 2013, the high burden of pollutants entering the bay from inland waters due to tourism activities, and increased sedimentation rates (Wisha et al., 2018). This is predicted to be aggravated if a reclamation is carried out which does not take into account environmental sustainability. So that environmental intervention and technology engineering is needed as rehabilitation efforts so that environmental sustainability can be improved. In planning a development in the sea, coastal and small island areas must pay attention to the principles of spatial patterns and ecosystem conditions in the region play an important role in maintaining the sustainability of marine resources and the coast (Diposaptono, 2011).

From the viewpoint of the environment, the whole ecosystems in Benoa Bay are important for Bali Island. Benoa Bay is not only the area for the mangrove ecosystem but also used for waste disposal. Therefore, understanding of the characteristics of the seawater circulation is important in order to conserve the marine environment in the bay (Hendrawan \& Asai, 2014). The shallow waters around the Island are inhabited by macrophytes. A coral reef to the east of Serangan Island forms a border to the ocean. The water on the coral reef flats and slopes is clear, has low nutrient levels, and is well saturated with respect to oxygen (Bach et al., 1998).

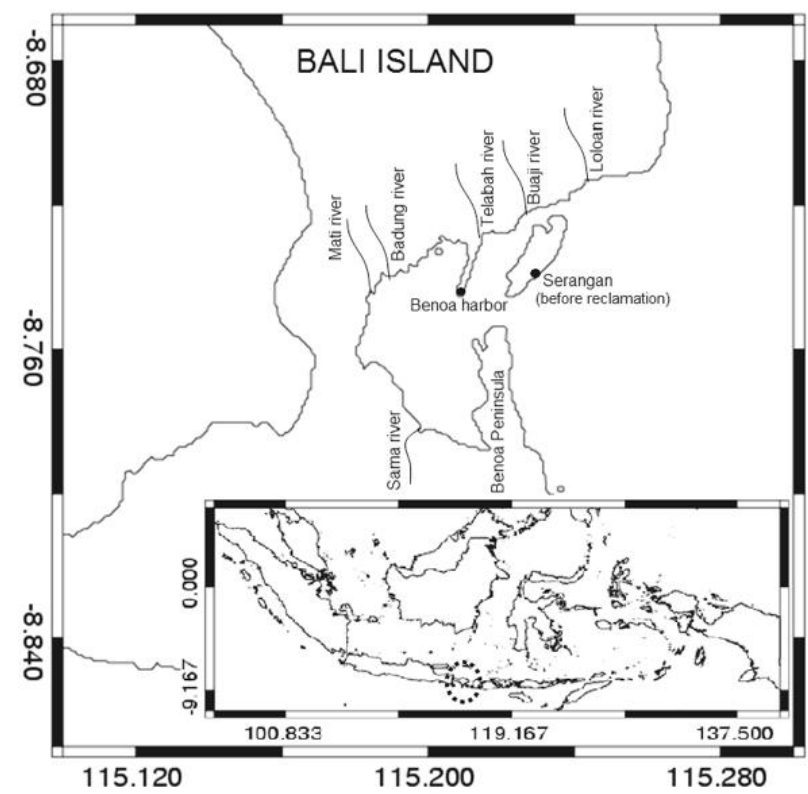

Figure 3: Map of River Flow that Disembogue into the Benoa Bay

Source: (Hendrawan \& Asai, 2014)

Nowadays, Benoa Bay is undergoing of siltation, the trigger is due to sedimentation from the downstream area of five 
rivers to the bay. The Benoa Bay is under the leverage of the six rivers downstream: the Badung River, the Mati River, the Sama River, the Telabah River, the Loloan River, and the Buaji River. Those six rivers disembogue to the Benoa Bay creating estuaries and typologies that are different from other shallow coastal waters. Where live a number of strategic communities, especially mangrove, seagrass, seagrass, coral reef, and macrozoobenthos communities with high abundance and diversity (Putra, 2017).

Although the project will cause a huge environmental change, the investors never directly mention to the public regarding the environmental degradation risk of the project. On the contrary, they repeatedly say that the project will restore the environment in the area (Wiranata, 2016).

Based on the academic study of the Institute of Research and Community Service of Udayana University (Unud) stated that the plan for the reclamation of the Benoa Bay will have many adverse effects on the environment. The final results of the Unud feasibility study state that the reclamation of Benoa Bay is not feasible. There are four aspects of the study in the feasibility study, namely technical, environmental, socio-cultural, and financial-economic aspects. The results of the study of the four aspects were all declared to be inappropriate. Viewed from the environmental aspect, Benoa Bay is a sea lane and is a conservation area.

Benoa Bay area as the only fortress that naturally functions to protect the area of South Bali from various disasters such as floods, tsunamis, and others. Benoa Bay is also the estuary of a number of large rivers stretching on the island of Bali, such as Tukad Badung and Tukad Mati. In that area is also a place for spawning fish that will breed. If reclamation is still carried out, the fish in the mangrove forest will be trapped, unable to return to the sea which will lead to the death of the fish. If the amount of fish is reduced, the catch of fishermen is minimal. In addition, it will reduce the waves on other beaches because it is split in Benoa Bay.

Based on Handadari A S K research of the respondents' discussion and literature review, the waters of Benoa Bay have indeed suffered damage and pollution since Serangan Island reclamation (1996), toll road construction, the high load of pollutants entering the bay from inland waters due to tourism activities, port activities, and increased sedimentation. The environmental conditions in Benoa Bay and the estimated impacts from the reclamation activities in the Benoa Bay are presented based on the physical, chemical, and ecosystem aspects in Benoa Bay (Handadari \& Pranowo, 2018). Environmental conditions Benoa Bay will be less sustainable if carried out reclamation. Management interventions for increasing the value of sustainability can provide attributes with high sensitivity, i.e. sedimentation and fish resources (Handadari, 2018).

\section{Impact of Policy Change}

The Indonesian government is trying to build inclusive governance. Inclusive means that contributing all stakeholders to collaboration between governments, scientists, businessmen, and civil society organizations to the process of policymaking (Renn \& Schweizer, 2009).

Reclamation (in UNCLOS stated as artificial islands) can impact other countries so that there must be rules that governing coastal reclamation internationally. United Nations Convention on the Law of the Sea (UNCLOS) 1982 consists of 17 chapters, 320 articles, and 9 attachments signed in Montego Bay, Jamaica, 10 December 1982 and entered into force on 16 November 1994, an agreement consisting of a regulatory framework in the use of resources marine power, among others, to ensure the conservation and availability of use of marine resources and the maritime environment and ensure the protection and maintenance of the sustainability of marine resources have been ratified by 161 countries including Indonesia ratified by the issuance of Law No. 17 of 1985 concerning Ratification of UNCLOS 1982. On Article 196 about the Use of technologies or the introduction of alien or new species stated that "States shall take all measures necessary to prevent, reduce and control pollution of the marine environment resulting from the use of technologies under their jurisdiction or control, or the intentional or accidental introduction of species, alien or new, to a particular part of the marine environment, which may cause significant and harmful changes thereto". It is explained that the state is required to take measures to prevent, reduce and control the pollution of the marine environment as a result of the use of technologies into certain parts of the marine environment such as the example of conducting reclamation.

The policy that the government made was made a huge environmental impact to the Benoa Bay. Because it changed the status of Benoa Bay from a conservation area to an exploitation area that can be a threat to the marine ecosystem and the migratory species that we explained above.

\section{The Impact of Policy For Social At Benoa Bay}

\section{Socio-cultural Impact}

Development in the broadest sense is an effort to change the condition of a nation for the better. Development is associated with state goals generally carried out in order to realize a just and prosperous society. One indicator of the success of development when the country can meet the basic needs of society in a country.

Based on United Nation, indigenous peoples, communities, and nations are those which have a historical continuity with preinvasion and pre-colonial societies that be expanded on their areas, consider themselves distinct from other sectors of 
societies now prevailing in those areas, or parts of them. Natural resources and the environment are the most interesting things in indigenous knowledge, which was reflected by the emersion of indigenous environmental knowledge concepts. (Dove, 2006).

For those who live adjacent to the marine environment and who rely on it, access to both marine resources and areas of the ocean and coast is a particularly important issue (Bennett et al., 2018). Based on previous research, a reclamation development plan at Benoa Bay can cause not only environmental damages but also damages of traditional/cultural sites. At that time, there were estimates of significant impacts in the process of environmental impact analysis, clearly having an impact on the chemical parts of marine biology, geophysics, culture and social, community, and health mandated in the Law number 27 the year 2007 j.o Law number 1 the year 2014. Whereas in the socio-cultural side of that deeply affected and has an important impact was the contamination and even destruction of the sacred area located in the Benoa Bay as one of the traditional cultural sites. In the previous research, there were findings 60 holy sites with a traditional culture where religious rituals existed in some villages around Benoa Bay (Ardhana \& Farhaeni, 2017).

\section{Background of the Social Movement}

Protest movements in Indonesia resist the government's liberal development policies and the destruction of culture and environment through capitalist intrusion and land (or sea) grabbing (Bräuchler, 2019). The social conflict approach of political economy, favored by Jones, is based on an understanding of power and resources in society resulting from the outcome of contestations between socio-political coalitions, whose relative strength is shaped by historically contingent structures of social, economic, and political inequality, rooted in the political economy (Scarpello, 2018).

One of the reactions or responses most of the Balinese have given to the policy of the Benoa Bay reclamation is rejection (Catur, 2019). As a development plan of Benoa Bay Reclamation, the Balinese people will not stop to fight against that development plan. This can be seen from the number of banners and billboards installed on the Bali streets. The rejection came from at least 30 Adat Villages that have more than 100 customary law, lots of people and the community rejected that Benoa Bay area to be destroyed because of the reclamation.

The resistance movement against the Benoa Bay reclamation policy began when the Governor's Decree was known to the public. The decree is considered problematic by the community. Governor's Decree is contrary to Presidential Regulation No. 45 of 2011 which states that Benoa Bay as a conservation area should not be utilized or reclaimed. However, the central government during the administration of Susilo Bambang Yudhoyono actually supported the reclamation plan of Benoa Bay. Presidential Regulation No. 45 of 2011 was revoked and replaced with Presidential Regulation No. 51 of 2014 which made the status of Benoa Bay a cultivation area that could be utilized and developed. The emergence of these policies and public awareness of the negative impacts that occurred led to a resistance movement consisting of environmentally concerned communities, activists, environmental movements that formed an organization called ForBALI. Formed in 2013, the group is the driving force behind "tolak reklamasi" (reject reclamation), the biggest resistance movement against the proposed project (Coconuts Bali, 2019). In addition, a resistance movement emerged from indigenous villages. Traditional villages reject the reclamation plan because it will clash with religious, social, and cultural values in Bali.

The traditional village resistance movement was started by the traditional coastal villages of Benoa Bay. The traditional villages that reject reclamation are the traditional villages of Tanjung Benoa, Kedonganan, Kerobokan, Jimbaran, Seminyak, Kelan, Kuta, Legian, Canggu, Berawa, Buduk, and Bualu Badung regencies. In addition, the traditional village of Pedungan, Kepaon, Pemogan, Sesetan, Serangan, and Sanur is located in Denpasar city as well as traditional villages from Gianyar regency, namely the traditional village of Cucukan, Keramas, Mendahan, and Ketewel. The traditional coastal villages of the Benoa Bay were the first wave of traditional villages which carried out a resistance movement against the Benoa Bay reclamation policy. Because, the beginning of the emergence of the movement was begun by coastal villages and there was still nothing to be seen if there were other traditional villages which carried out an insurgency (Hapsari \& Komang, 2014).

After the traditional village resistance movement expanded the first wave, the resistance movement emerged from the traditional village far from the coast of Benoa Bay. The traditional villages far from the coast of the Tanjung Benoa that took part in the resistance movement were the traditional Jaheim and Serokadan villages from Bangli district. In addition, the traditional village of Kusamba, the traditional village of Paksebali, and hundreds of people on behalf of themselves Klungkung Youth. At the end of April 2016, the phenomenon of the indigenous village resistance movement that was far from the coast of Benoa Bay, namely the Pasedahan customary village, Manggis district, Karangasem district, one of the traditional villages far from the Benoa Gulf coast, took part in rejecting the reclamation in Benoa Bay. In terms of territory, Pasedahan traditional villages are far from the sea coast and do not have the sea. The beginning of the emergence of resistance movements at the time of the Adat Bendesa and some indigenous village communities followed the Dharma Wacana. There they got all the understanding of the Benoa Bay area as a sanctified area.

They believe that with the reclamation, the sanctified areas will disappear especially the reclamation they know is by conducting sea billing which will be allocated to become artificial islands for tourism purposes such as the construction of hotels, public places, and other modern tourism. In addition to Benoa Bay, it is believed to be a sacred area that has 60 sacred points scattered in the area, which is believed to be a meeting / unifying area of Sekala-Niskala Tanjung, 
Jimbaran, Kelan, Tuban, Pesanggaran, Benoa, Serangan dan Sanur. The sacred points consist of 23 temples, 1 Taru Agung, 17 loloan, 2 sawangan, and 17 muntig, and especially the Pasedahan traditional village community believes that reclamation is very clashing with the concept of Tri Hita Karana as a guideline for indigenous people on the island of Bali.

The existence of water meeting points such as loloan (confluence of rivers and seas) and campuhan that are purified, sacred, and become a place or as a sacred point in the implementation of Upakara (religious ceremonies). Various Upakara were carried out in the area, because of the Balinese people's belief that the existence of universal energy was met at that point and gave kerahayuan (purity of the soul). Besides that, the reclamation of Benoa Bay collided with Tri Hita Karana concept which became the guideline of traditional villages and Hindu communities in Bali. These things involving three concepts, namely; Parahyangan (human relationship with God), Pawongan (human relationship with human cooperation), and the last is Palemehan (the relationship between humans and nature) (Rena \& Putu, 2015).

In response to the revision of Presidential regulation, activists have conducted a series of demonstrations and protests in an effort to restore the status of Benoa Bay to a conservation area. The protest involved many people, ranging from fishermen to artists and activists and environmentalists. Benoa bay also a sacred place for Bali traditional community, If the sea level is decreased, the fish can be caught by the people.

The developer of this reclamation project is PT TirtaWahana Bali Internasional (PT TWBI), are a property development and management company based in Bali. PT TWBI becomes a pioneer in developing and managing an upcoming new tourism area in Bali while respecting the Balinese philosophy of "Tri Hita Karana", in which promotes the threephilosophy well-being harmony with God, among people, and the environment. PT TWBI thrives for innovation and quality excellence in creating a new prime tourism area that can be a pride for Bali and Indonesia. Through one of its strategic project, the Revitalization of Benoa Bay, the company is moving forward to achieve its vision of becoming one of the best development and area management company in Bali, committed towards integrating local wisdom and bringing positive environmental and social impact (About PT Tirta Wahana Bali International, www.twbi.co.id). But the facts are not as described.

\section{Impact of Policy Change}

Integrated Coastal Zone Management (ICZM) is a concept that offers the idea of sustainable coastal management with the participation of all stakeholders to manage diverse coastal resources. Hence the ICZM policy must be a collaboration of all stakeholders (Sukardjo, 2002).

One of the reclamation developments that have been built in the coastal area of benoa bay is the reclamation of Pudut Island, the reclamation is carried out because the island is prone to tsunamis and almost submerged due to climate change. Reclamation of product island is a good example of reclamation because reclamation is built to revitalize the island so that the island does not submerge (Ardhana \& Farhaeni, 2017). Local governments where the reclamation project is taking place also do not have adequate policies to protect marine waters and coastal areas (Kamim, 2020).

The location permit was issued for the first time by Tjitjip Sutarjo as the Minister of Maritime Affairs and Fisheries in the era of President Susilo Bambang Yudhoyono, which was valid for two years from 25 August 2014 to 25 August 2016. Then, the legal consequences of the issuance of the location permit, PT TWBI has the right to make an Environmental Impact Assessment (EIA), and if the EIA is feasible, the Indonesian Minister of Environment and Forestry will issue a Decree on Environmental Feasibility (Adharani et al., 2019). Minister of Environment and Forestry Indonesia in several media said that the EIA document prepared by PT TWBI could not be said to be feasible because it still could not overcome the socio-cultural impact. It means that PT TWBI EIA is not feasible because of the massive rejection from the Balinese people, both from the Adat Village. On August 25, 2018, the deadline for the reclamation permit of Benoa Bay. Until now, the Minister of Environment and Forestry doesn't issue the Decree on Environmental Feasibility so that the EIA was expired so that the location permit for the reclamation of Benoa Bay cannot be issued. But it isn't over yet, because benoa bay still a commercial area based on Presidential Decree No. 51 the Year 2014.

The development plan triggered a backlash from the Balinese public. Accused, during hearings involving academics, NGO activists, religious and local customary (adat) leaders, of violating higher regulations, the Governor revoked his first decision. In lieu of the cancelled utilization permit, he issued a new decision granting TWBI 'Permission to Conduct Feasibility Studies for the Plan to Utilise, Develop and Manage the Water Areas of Benoa Bay'. The new executive decision now provides a legal ground for the company to undertake a feasibility study within the proposed areas as the first stage in the process to obtain environmental and operational permits (Wardana, 2018).

The reclamation of Benoa Bay has not reached the stage of physical development, but only limited to regulations and permits that allow reclamation. In the implementation of reclamation, there are 2 permits that must be fulfilled, location permit, and execution permit. However, to get a location permit, it must make the EIA first. On August 25, 2018, is considered as the validity period of the Reclamation Location Permit held by PT TWBI until that date the EIA is not issued, the Location Permit is no longer valid and the Reclamation of Benoa Bay on a project scale must be stopped (Suriyani, 2018). In theory, EIA can be issued in the form of a decent or inappropriate decision, the decision from the 
Ministry of Environmental and Forestry said that the EIA of Benoa Bay Reclamation is not feasible for the social aspects.

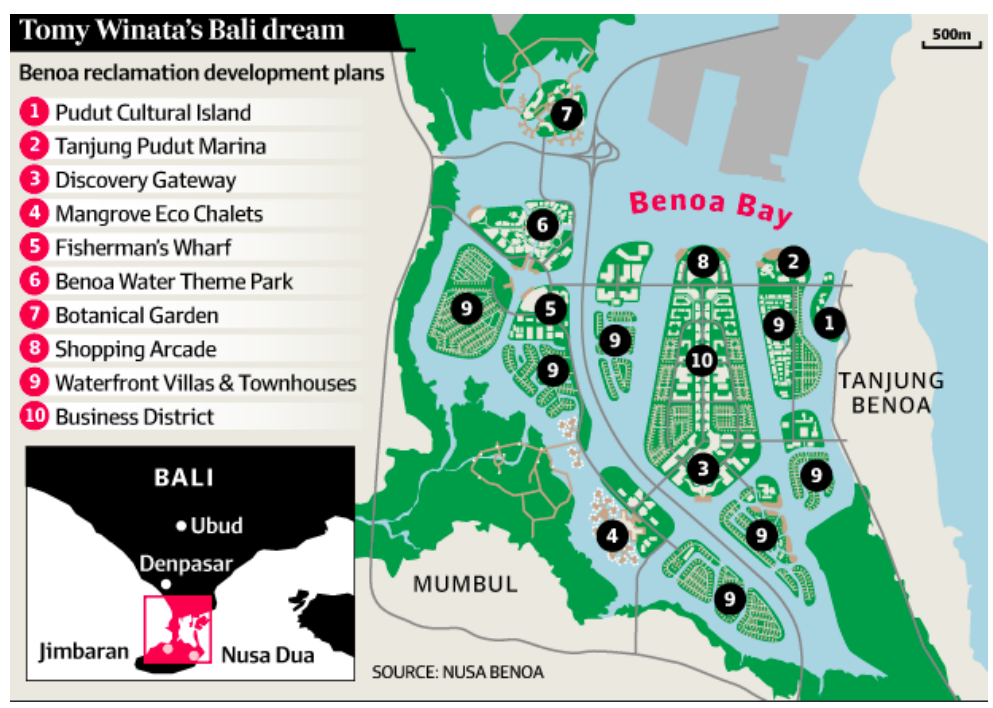

Figure 4: Reclamation Plan of Benoa Bay

Source: For BALI, 2018

For more than 5 years, communities that concerning about conservation in Benoa Bay (FOR BALI) have not stopped doing an action. Until August 25, 2018, the location permit was owned by PT. Tirta Wahana Bali Internasional (TWBI) has expired and the EIA of the reclamation project has been declared inadequate. However, the Indonesian Minister of Maritime Affairs and Fisheries, Susi Pudjiastuti, suddenly issued a new location permit to the same investor on 29 November 2018. The rise of resistance from the community can be a consideration of the government, especially the President, to carry out policies that are pro-people, and revoked the Presidential Decree 512014.

\section{CONCLUSION}

Policy change on Benoa Bay status affected social and environmental aspects. The policy that the government made was made a huge environmental impact on Benoa Bay. The status changed of Benoa Bay from a conservation area to an exploitation area can be a threat to the marine ecosystem and the migratory species, because in Presidential Regulation Number 54 the Year 2014 stated that can develop reclamation in Benoa Bay. Balinese people who are members of the Bali People's Forum Refuse the Reclamation of Benoa Bay (ForBALI) have not stopped doing the action. Until August 25, 2018, the location permit was owned by PT. Tirta Wahana Bali Internasional (TWBI) has expired and the EIA of the reclamation project has been declared inadequate.

However, the Indonesian Minister of Maritime Affairs and Fisheries, Susi Pudjiastuti, suddenly issued a new location permit to the same investor on 29 November 2018. The rise of resistance from the community can be a consideration of the government, especially the President, to carry out policies that are pro-people, and revoked the Presidential Regulation 512014.

In policy-making, the government should pay attention to philosophical, juridical, and social aspects, in this case, the social aspects cannot be fulfilled because the revision of the presidential regulation makes people feel disadvantaged. Policy or decision making is must build upon the use of the best information and the best science available. In some circumstances it is should give focus on social, cultural, and economic factors provided irreversible damage is not done to the ecosystem in the process and unsustainable practices are not put in place. Scientific information is required to indicate the thoughtful use of coastal resources, to protect the environment, and to improve the quality of coastal zone residents' life.

The reclamation of Benoa Bay has not reached the stage of physical development, but only limited to regulations and permits that allow reclamation. In the implementation of reclamation, there are 2 permits that must be fulfilled, location permit, and execution permit. However, to get a location permit, it must make the EIA first. Policy changed in Benoa Bay should be as a unity of ecological, social, and economic issues.

\section{LIMITATIONS AND STUDY FORWARD}

This research comprises a few restraints such as (i) the impact of the Indonesian Government policy-making on the Benoa Bay Reclamation Plan, (ii) the impact of the Benoa Bay Reclamation Plan to environmental sustainability and social/local community in Bali. This research can still be developed for a more recent final result, so that the imminent researchers could probably add more the up to date variable so that the final result can be more deeply. 


\section{ACKNOWLEDGEMENT}

The authors are grateful for the kindness of the Balinese Anti-Reclamation Forum (ForBali) and Wahana Lingkungan Hidup (Walhi) Bali to provided us data and such an interesting discussion. We also thank the Indonesian Ministry of Environment and Forestry and the Indonesian Ministry of Maritime and Fisheries Affairs to provide us data to complete this research. This study was funded by Universitas Padjadjaran Research Grant 2018 and submitted via The Center of Environmental and Spatial Planning Law of Faculty of Law Universitas Padjadjaran.

\section{AUTHORS CONTRIBUTION}

The first author was responsible for proposing the research idea as well as exploring the existing literature to be the basis for analysing and discussion of this study. The second author was responsible for analysing the data and providing the interpretation of the analysis result. The third author was responsible for concluding, reviewing, and editing the whole paper.

\section{REFERENCES}

1. Adharani, Y., Nurlinda, I., Astriani, N., Zamil, Y. S., \& Afifah, S. S. (2019). Jakarta Bay Reclamation: The Challenge Between Policy, Environmental and Social Impacts. IOP Conference Series: Earth and Environmental Science. https://doi.org/10.1088/1755-1315/306/1/012025

2. Ardhana, I. P. G., \& Farhaeni, M. (2017). The study of the impact for social culture toward the planning of reclamation for Benoa Bay in Bali. AIP Conference Proceedings. https://doi.org/10.1063/1.4983437

3. Article 26 Presidential Regulation of The Republic of Indonesia Number 122 concerning Reclamation in Coastal Areas and Small Islands. (2012). Indonesia.

4. Asri, S. K. H, Tri E. B. S., \& Widodo S. P. (2018). Indeks Keberlanjutan Sumber Daya Laut dan Pesisir di Lokasi Reklamasi Teluk Benoa Bali. Jurnal Kelautan Nasional, 3(13).

5. Bach, H. K., Rasmussen, E. K., \& Foster, T. (1998). Eutrophication modelling of a tidally influenced mangrove area in Bali subject to major dredging and reclamation activities. International Conference on Environmental Problems in Coastal Regions.

6. Bennett, N. J., Kaplan-Hallam, M., Augustine, G., Ban, N., Belhabib, D., Brueckner-Irwin, I., \& Foley, P. (2018). Coastal and Indigenous community access to marine resources and the ocean: A policy imperative for Canada. Marine Policy, 87, 186-193. https://doi.org/10.1016/j.marpol.2017.10.023

7. Black, F. F. (2016). Greening Environmental Policy: The Politics of a Sustainable Future. Springer. Retrieved from https://books.google.co.id/books?hl=en\&lr=\&id=4FcBDgAAQBAJ\&oi=fnd\&pg=PP1\&dq=environme

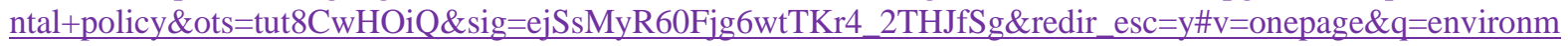
ental\%20policy\&f=false

8. Boak, E. H., \& Turner, I. L. (2005). Shoreline Definition and Detection: A Review. Journal of Coastal Research, 21 (4 (214)): 688-703. https://doi.org/10.2112/03-0071.1

9. Bräuchler, B. (2019). Brokerage, Creativity and Space: Protest Culture in Indonesia. Journal of Intercultural Studies, 40(4), 451-468. https://doi.org/10.1080/07256868.2019.1628721

10. Böhnke-Henrichs, C. B. (2013). Typology and Indicators of Ecosystem Services for Marine Spatial Planning and Management. Journal of Environmental Management, 130, 135-145. https://doi.org/10.1016/i.jenvman.2013.08.027

11. Catur N. I. P. (2019). The Movement of Bali Reject Reclamation (The Phenomenological Study Of Balinese Society Movement Rejects Benoa Bay Reclamation Among \#ForBALI Alliances). Profetik Jurnal Komunikasi, 12(1), 22. https://doi.org/10.14421/pjk.v12i1.1541

12. Cearreta, A., Irabien, M. J., Ulibarri, I., Yusta, I., Croudace, I. W., \& Cundy, A. B. (2002). Recent salt marsh development and natural regeneration of reclaimed areas in the Plentzia Estuary, n. Spain. Estuarine, Coastal and Shelf Science. https://doi.org/10.1006/ecss.2001.0862

13. Coconuts Bali. (2019, March 25). ForBALI chides govt. officials' handling of Benoa Bay reclamation project during protest. Retrieved from COCONUTS BALI: https://coconuts.co/bali/news/forbali-march-benoa-bayreclamation-call-govt-officials-alleged-rejection-project/

14. Dafforn, M. M.-P. (2015). Application of Management Tools to Integrate Ecological Principles with The Design of Marine Infrastructure. Journal of Environmental Management, 158, 61-73. https://doi.org/10.1016/i.jenvman.2015.05.001

15. Dale, P., Sporne, I., Knight, J., Sheaves, M., Eslami-Andergoli, L., \& Dwyer, P. (2019). A conceptual model to improve links between science, policy and practice in coastal management. Marine Policy, 103, 42-49. https://doi.org/10.1016/j.marpol.2019.02.029

16. Dewi, I. G. (2019). Penolakan Masyarakat Terhadap Reklamasi Teluk Benoa Provinsi Bali. Diponegoro Law Review, 4(1), 391. Retrieved from https://ejournal2.undip.ac.id/index.php/dplr/article/download/5023/2645

17. Dharma, I. G. B. S., \& Candrayana, W. (2017). Hydrodynamics and Sediment Transport of Benoa Bay, SemiEnclosed Bay in Bali, Indonesia. Applied Mechanics and Materials. https://doi.org/10.4028/www.scientific.net/AMM.862.3

18. Diposaptono, S. (2011). Sebuah Kumpulan Pemikiran Mitigasi Bencana dan Adaptasi Perubahan Iklim. 
Jakarta. Jakarta: Direktorat Pesisir dan Lautan, Dirjen KP3K, KKP.

19. Dove, M. R. (2006). Indigenous People and Environmental Politics. Annual Review of Anthropology. https://doi.org/10.1146/annurev.anthro.35.081705.123235

20. DW. (2016, August 25). Chaotic on The Island of The Gods: Some Balinese People Reject Benoa Bay Reclamation. Retrieved August 06, 2020, from DW Made for Minds: https://www.dw.com/id/kisruh-di-pulaudewata-sebagian-warga-bali-tolak-reklamasi-teluk-benoa/a-19502209

21. Eden, S. (2016). Public Participation in Environmental Policy: Considering Scientific, Counter-Scientific and Non-Scientific Contributions. Public Understanding of Science. Retrieved from https://citeseerx.ist.psu.edu/viewdoc/download?doi=10.1.1.571.9618\&rep=rep1\&type=pdf

22. Ehrlich, P. R., \& Holdren, J. P. (1971). Impact of population growth. Science, 171(3977), 1212-1217. https://doi.org/10.1126/science.171.3977.1212

23. Fabricius, K. E. (2011). Factors determining the resilience of coral reefs to eutrophication: A review and conceptual model. In Coral Reefs: An Ecosystem in Transition. https://doi.org/10.1007/978-94-007-0114-4_28

24. Field, C. B., Behrenfeld, M. J., Randerson, J. T., \& Falkowski, P. (1998). Primary production of the biosphere: Integrating terrestrial and oceanic components. Science. https://doi.org/10.1126/science.281.5374.237

25. Foxwell-Norton, K. (2017). Environmental Communication and Critical Coastal Policy: Communities, Culture and Nature. Routledge. https://doi.org/10.4324/9781315757056

26. Gokkon, B. (2019, October 11). Bali Mangrove Bay is Now a Conservation Zone, Nixing Reclamation Plan. Retrieved August 06, 2020, from Mongabay: https://news.mongabay.com/2019/10/bali-benoa-bay-mangrovesconservation-reclamation/

27. Handadari, A. S. K. \&. Pranowo, W. (2018). Analysis of Marine and Coastal Resources Sustainability in Benoa Coastal Bay Reclamation Site. EDP Sciences, 74, 02002. https://doi.org/10.1051/e3sconf/20187402002

28. Handadari, T. S. (2018). Indeks Keberlanjutan Sumber Daya Laut dan Pesisir di Lokasi Reklamasi Teluk Benoa Bali. Jurnal Kelautan Nasional, 13(3), 121-136. Retrieved from http://ejournalbalitbang.kkp.go.id/index.php/ikn/article/download/6973/pdf

29. Hapsari, A. I., \& Komang, N. L. (2014). Regulasi Tanpa Basic Sumber Daya Alam Dan Lingkungan Sosial (Studi Penerapan Peraturan Presiden Nomor 51 Tahun 2014 tentang Perubahan Atas Peraturan Presiden Nomor 45 Tahun 2011 tentang Rencana Tata Ruang Kawasan Perkotaan Denpasar, Badung, Gianyar, dan T.

30. Hendrawan, I. G., \& Asai, K. (2014). Numerical Study on Tidal Currents and Seawater Exchange in the Benoa Bay, Bali, Indonesia. Acta Oceanologica Sinica. https://doi.org/10.1007/s13131-014-0434-5

31. Holmes, J. R. (2008). Enhancing The Use of Science in Environmental Policy-Making and Regulation. Environmental Science \& Policy, 11(8), 703. https://doi.org/10.1016/j.envsci.2008.08.004

32. Imasato, N., Awaji, T., \& Kunishi, H. (1980). Tidal exchange through Naruto, Akashi and Kitan Straits. Journal of the Oceanographical Society of Japan. https://doi.org/10.1007/BF02072060

33. Jiping, S. H. (2016). An Analysis of Spatial Distribution of Marine Environmental Policy in Coastal Areas. Journal of Southwest Petroleum University, 5(4). Retrieved from http://search.cnki.net/down/default.aspx?filename=PXSY201605004\&dbcode=CJFD\&year=2016\&dflag=pdfd $\underline{\text { own }}$

34. Kamim, A. B. (2020). Ocean Grabbing di Indonesia dan Malaysia: Catatan Krisis Sosio-Ekologis Dampak Proyek Reklamasi. Aspirasi: Jurnal Masalah-masalah Sosial, $11(1), \quad 105-120$. https://doi.org/10.46807/aspirasi.v11i1.1587

35. Lester, S. E., Stevens, J. M., Gentry, R. R., Kappel, C. V., Bell, T. W., Costello, C. J., ... \& Simons, R. D. (2018). Marine spatial planning makes room for offshore aquaculture in crowded coastal waters. Nature Communications, 9(1), 1-13. https://doi.org/10.1038/s41467-018-03249-1

36. Ma, Y., Cao, H., Zhang, L., \& Fu, Z. (2020). Relationship Between Local Government Competition, Environmental Regulation and Water Pollutant Emissions: Analysis Based on Mediating Effect and Panel Threshold Model. Journal of Coastal Research, 103(SI), 511-515. Retrieved from https://doi.org/10.2112/SI103-103.1

37. Marshall, N. A. (2017). Empirically Derived Guidance for Social Scientists to Influence Environmental Policy. PLoS One, 12(3). https://doi.org/10.1371/journal.pone.0171950

38. Ministry of Public Works Indonesia. (n.d.). Applied Modules Guideline for Spatial Planning of the Coastal Reclamation Area of Ministry of Public Works Indonesia No. 40 / PRT / M / 2007.

39. Noble, B. (2012). Introduction to Environmental Impact Assessment: a Guide to Principles and Practice. Oxford: Oxford University Press.

40. Percival, R. V., Schroeder, C. H., Miller, A. S., \& Leape, J. P. (2017). Environmental Regulation: Law, Science, and Policy. Wolters Kluwer Law \& Business, 3. Retrieved from https://www.amazon.com/Environmental-Regulation-Science-Policy-Casebook/dp/1454822287

41. Priyanta, N. A. (2015). Buku Ajar Hukum Lingkungan. Bandung: CV Kalam Media.

42. Putra, T. T. (2017). Pendekatan Metode Normalized Difference vegetation Index (NDVI) dan Lyzenga untuk Pemeteaan Sebaran Ekosistem Perairan di Kawasan Pesisir Teluk Benoa-Bali. Jurnal Ilmiah Geomatika, 23(2), 87-94.Retrieved from https://www.researchgate.net/profile/Aprizon_Putra/publication/323999668_Pendekatan Metode_Normalized_Difference_Vegetation_Index_NDVI_dan_Lyzenga_untuk_Pemetaan_Sebaran_Ekosiste 
m_Perairan_di_Kawasan_Pesisir_Teluk_Benoa-Bali/links/5ab7fe9f45851515f59f4740

43. Rahmah, S. (2019). Perlindungan Hukum Terhadap Hak Masyarakat Nelayan Wilayah Pesisir. Dinamika: $\begin{array}{lllll}\text { Jurnal Ilmiah Ilmu Hukum, } & \text { 25(10). }\end{array}$ http://riset.unisma.ac.id/index.php/jdh/article/download/3513/3169

44. Rena, D. B., \& Putu, I. (2015). Civil Society Dalam Dinamika Pro-Kontra Rencana Reklamasi Teluk Benoa. Journal Universitas Airlangga.

45. Renn, O., \& Schweizer, P. J. (2009). Inclusive risk governance: Concepts and application to environmental policy making. Environmental Policy and Governance. https://doi.org/10.1002/eet.507

46. Rizal, A. (2018). Science and Policy in The Coastal Zone Management. World News of Natural Sciences, $21,1-$ 8.Retrieved from https://www.researchgate.net/profile/Achmad_Rizal7/publication/327837720_Science_and policy in the coastal zone management/links/5ba8b40e92851ca9ed217f59/Science-and-policy-in-thecoastal-zone-management.pdf

47. Scarpello, F. (2018). Beyond Copenhagen: The Political Economy of Securitising "Outside Influences" in Bali. Journal of Contemporary Asia, 48(1), 1-22. https://doi.org/10.1080/00472336.2017.1362583

48. Shakeela, S. B. (2015). Gaps and Disincentives That Exist in The Policies, Laws, and Regulations which Act as Barriers to Investing in Climate Change Adaptation in The Tourism Sector of The Maldives: Increasing Climate Change Resilience of Maldives Through Adaptation in... Retrieved from Saruna.mnu.edu.mv: http://saruna.mnu.edu.mv/jspui/bitstream/123456789/1324/1/Gaps-And-Discentives.pdf

49. Soehoed, A. R. (2004). Reklamasi Laut Dangkal: Canal Estate Panti Mutiara Pluit, Perekayasaan dan Pelaksanaan Reklamasi bagi Proyek Pantai Mutiara di Pluit-Jakarta. Jakarta: Djambatan.

50. Soekanto, S., \& Mamudji, S. (1994). Penelitian Hukum Normatif, Suatu Tinjauan Singkat. Bandung: Alumni.

51. Stocker, N. H. (2015). Coastal Residential Waterways, Science and Policy-Making: The Australian Experience. Estuarine, Coastal and Shelf Science, 155, A1-A13. https://doi.org/10.1016/j.ecss.2014.12.019

52. Strzałkowski, P., \& Kaźmierczak, U. (2019). The Scope of reclamation works for areas after the exploitation of rock raw materials. Applied Sciences, 9(6), 1181. https://doi.org/10.3390/app9061181

53. Sukardjo, S. (2002). Integrated Coastal Zone Management (ICZM) in Indonesia: A view from a mangrove ecologist. Southeast Asian Studies.

54. Suriyani, L. D. (2018, August 30). As Bali reclamation project dies, activists seek conservation status. Retrieved from Mongabay: https://news.mongabay.com/2018/08/as-bali-reclamation-project-dies-activistsseek-conservation-status/

55. Tarigan, M. I. T. T. (2020). Strengthening International Law as a Guarantee for High Seas Fisheries Conservation. Bina Hukum Lingkungan, 4(2), 332. https://doi.org/10.24970/bhl.v4i2.136

56. Triana, R. Y. (2019, October). Access to Justice of Balinese: Community Struggle to Refuse Benoa Bay Reclamation Plan. In 3rd International Conference on Globalization of Law and Local Wisdom (ICGLOW 2019). Atlantis Press. https://doi.org/10.2991/icglow-19.2019.85

57. Wardana, A. (2017). Neoliberalisasi Kawasan Perairan Teluk Benoa: Sebuah Catatan Kritis atas Praksis Perlawanan di Bali. Jurnal Transformasi Sosial(35), 55. Retrieved from https://insistpress.com/wpcontent/uploads/2017/12/Agung-Wardana_Wacana-35-XIX-2017 55-90-watermark.pdf

58. Wardana, C. W. (2018). Sustaining The Unsustainable? Environmental Impact Assessment and Overdevelopment in Bali. Asia Pacific Journal of Environmental Law, 21(2), 101-125. https://doi.org/10.4337/apjel.2018.02.02

59. Wiranata, S. M. (2016). The Contestation of Discourses on Sustainable Development in The Controversy of Benoa Bay Reclamation. International Conference on Contemporary Social and Political AffairPROCEEDING RE-EXAMINING GOVERNANCE: STRENGTHENING CITIZENSHIP IN THE CHANGING WORLD (p. 277). Surabaya: The Faculty of Social and Political Science Universitas Airlangga. Retrieved from https://www.researchgate.net/publication/326489219_The_Contestation_of_Discourses_on_Sustainable_Devel opment in the Controversy of Benoa_Bay Reclamation

60. Wisha, U. J., Tanto, T. Al, Pranowo, W. S., \& Husrin, S. (2018). Current movement in Benoa Bay water, Bali, Indonesia: Pattern of tidal current changes simulated for the condition before, during, and after reclamation. Regional Studies in Marine Science. https://doi.org/10.1016/j.rsma.2017.10.006 